\title{
The effect of Sitagliptin (Januvia) on the liver of adult Albino rats in cases of experimental diabetes mellitus(Microscopic and laboratory studies)
}

\author{
Moustafa I. Hassan ${ }^{1}$ Gamal S.El-Gharabawy ${ }^{1}$ and Abdel-Ghany A. Moustafa ${ }^{2}$ \\ 1- Histology Department, Faculty of Medicine \& 2- Histology Department, Faculty of Medicine \\ (Dommiata) ,Al-Azhar University
}

\begin{abstract} liver of experimentally induced diabetes in albino rats. induction. Sitagliptin. risk of diabetes Mellitus on liver tissue.

\section{Review of Literatures}

The liver has a wide range of functions, including detoxification, protein synthesis and production of biochemicals necessary for digestion, glycogen storage, decomposition of red blood cells and hormone production, (Maton et al., 1993). Hepatocytes make up 70 to $80 \%$ of the total mass of the liver.
\end{abstract}

Introduction: The present study was carried out to evaluate the effect of Sitagliptin (Januvia) on the

Material and Methods: Fifteen adult male albino rats were used and divided into three equal groups. The first group was considered as a control group. In the second group experimental induction of diabetes was performed by intraperitoneal injection of alloxan and left as a diabetic control for three weeks. The third group was consisted of rats of experimentally induced diabetes and treated by a daily dose of Sitagliptin (Januvia) as oral anti diabetic therapy for three weeks.

Two main parameters were performed; the first was microscopic and histochemical studies on the liver tissue while the second was laboratory evaluation of some liver functions.

Results: The hepatic tissue was affected by the experimental induction of diabetes in the form of cellular infiltration, hepatic cell cords disarrangement and vascular congestion after three weeks of

The fibrous elements as well as mucopolysaccharides contents were greatly reduced. Histochemical changes in the liver enzymes showed mild decrease. Liver function tests showed mild changes.

Diabetic changes were gradually returned back to its normal state after the use of daily oral dose of

Conclusions: The antidiabetic drug (Sitagliptin) could be considered a good therapy in limiting the

Keywords: Albino rats, Alloxan, Sitagliptin, structural and laboratory findings.

On year 2000 at least 171 million people worldwide suffer from diabetes mellitus, or $2.8 \%$ of the population, type II diabetes is by far the most common, affecting 90 to $95 \%$ of the U.S. diabetes population, (Lambert , 2002 and Wild et al, 2004).

Diabetes mellitus, often simply referred to as diabetes which is a group of metabolic syndrome characterized by high blood sugar level and classical symptoms of polyuria ,polydipsia and polyphagia . There are three main types of diabetes, Type I diabetes, results from the body's failure to produce insulin (insulin-dependent diabetes mellitus, IDDM or juvenile diabetes). Type II diabetes, results from insulin resistance, a condition in which cells fail to use insulin properly (non-insulin-dependent diabetes mellitus, NIDDM or adult-onset diabetes). Gestational diabetes; in pregnant women who have never had diabetes before and have a high blood glucose level during pregnancy. It occurs in about $2 \%-5 \%$ of all pregnancies and may improve or disappear after delivery (Rother, 2007).

Diabetic complications may be acute in the form of hypoglycemia, diabetic ketoacidosis, or nonketotic hyperosmolar coma. Serious long-term complications include cardiovascular disease, chronic renal failure and retinal damage, (Rother, 2007).

Pre-diabetes indicates a condition that occurs when a person's blood glucose levels are higher than normal but not high enough for a diagnosis of type II diabetes. Many people destined to develop type II diabetes spend 
many years in a state of pre-diabetes which has been termed "America's largest healthcare epidemic, (Handelsman, 2009).

Several methods have been used to induce diabetes mellitus in laboratory animals with variable success and many difficulties. Surgical removal of the pancreas is effective method; however, to induce diabetes at least 90-95\% of the pancreas has to be removed, (Akbarzadeh et al., 2007).

Induction of experimental diabetes in the rat using streptozotocin is very convenient and simple to use, (Ito, 1999). Streptozotocin injection leads to the degeneration of the Langerhans islets beta cells, (Ikebukuro et al., 2002 and Takeshita et al., 2006). Clinically, symptoms of diabetes are clearly seen in rats within 2-4 days following single intravenous or intraperitoneal injection of $60 \mathrm{mg} / \mathrm{kg} \quad \mathrm{STZ}$, (Elias et al., 1994).

There are now four classes of hypoglycemic drugs, Sulfonylureas, Metformin, Thiazolidinediones and Alphaglucosidase inhibitors. These drugs are approved for use only in patients with type II diabetes and are used in patients who have not responded to diet, weight reduction, and exercise.

Sitagliptin (Januvia) is an oral antidiabetic medicine that helps in controlling blood sugar levels. It acting through regulation of the insulin level in the blood.

Sitagliptin is used in cases of type II diabetes. It is sometimes used in combination with other anti diabetic medications, but is not for treating type I diabetes, (Herman et al., 2006).

\section{Material and Methods}

\section{Experimental animals:}

The present work was carried out on 15 mature male albino rats weighting $100 \pm 20$ gms.

The experimental animals were randomly divided into three groups (5/cage). The first group was considered as a control group while the rest of all animals were subjected to the induction of experimental diabetes mellitus by single intraperitoneal injection of freshly prepared alloxan in a dose
$120 \mathrm{mg} / \mathrm{kg}$ dissolved in saline solution, according to (Malaisse, 1982).

Half of the induced diabetic rats were left as a control diabetic group (second group) while the rest of animals represent the third group which were treated by the sitagliptin in a dose of $0.14 \mathrm{mg} / 100 \mathrm{gm}$ body weight, (Paget, 1964) for 21 days after the induction of the diabetes mellitus.

\section{Preparation of microscopic sections:}

Liver was obtained and fixed in neutral buffered formol saline, (Clayden, 1971) for 5 days, dehydrated ,cleared and embedded in a hard grade of paraffin for 4 hours.

Paraffin blocks were prepared and cut at 6 micrometers thickness using a rotary microtome.

Different staining techniques were used in this study including Heamtoxylin and Eosin stain, (Clayden, 1971).

The distribution of collagenous fibers was performed by the use of Mallory trichrome stain, (Tarkhan 1968), while periodic acidschiff reaction was used for the distribution of mucopolysaccharide contents in the liver tissues.

\section{Histochemical techniques:}

Frozen sections were cut at 15 micrometers thickness for demonstration of the different enzymatic activity.

Modified Gomori method for Alkaline phosphatase enzyme was used in this study, (Pearse, 1977). Nitroblue tetrazolium method, (Nachlas et al., 1957) was used for localizing the activity of Succinic deydrogenase enzyme in the hepatic tissue.

\section{Biochemical and laboratory data:}

\section{Collection of rat's serum:}

At the end of the experiment, animals were decapitated and blood samples were collected from the retro-orbital plexus. The samples were collected in clean dry graduated centrifuge tubes and left for 20 minutes to clot, then centrifuged at $5000 \mathrm{rpm}$, for 15 minutes.

Using pasture pipette about half of the supernatant serum was transferred into clean dry serology tubes for subsequent tests. Serum was separated and kept at $-20^{\circ} \mathrm{C}$ until analysis.

1. Assessment of serum glucose level: Serum glucose was estimated according to the enzymatic colorimetric method described by Trinder, (1984).

2. Determination of serum Insulin level: This method is carried out according to Reeves, (1983). 
3. Alanine aminotransferase (ALAT): It was determined according to Breuer, (1996).

4. Gamma-Glutamyltransferase (GGT): It was determined by kinetic method according to

Szasz and Persijn, (1974).

V. Statistical analysis: The obtained results were tabulated and statistically analyzed, Snedecor et al. (1980)

\section{Results}

\section{Microscopic changes:}

a. Control liver :

Sections in control liver stained by Hx\&E stain shows normal hepatocytes arranged in radiating cords from the central vein to the periphery of hepatic lobule. The cords are separated by hepatic sinusoids.

Hepatocyte contains single or sometimes double central nuclei. Region of portal tract shows the normal tract contents of hepatic artery, portal vein and bile duct. (Fig. $1,2)$.

The normal distribution of the collagenous fibers around the region of portal tract were demonstrated in (Fig. 3) by Mallory stain technique.

While the normal hepatocyte content of mucopolysacharride were seen in (Fig. 4).

The activity of alkaline phosphatese enzyme in the control group seen in the (Fig. 13), while the activity of succinic dehydrogenase enzyme can be seen in (Fig. 16). The obtained histochemical changes were confirmed quantitatively by the use of image anaylsis system and statistically analyzed

\section{b. Diabetic group:}

Induction of diabetes by alloxan greatly affect the normal structure of the different liver elements in the form of dilated congested central veins and hepatic cell cords disarrangement. (Fig. 5,6)

The distribution of collagenous fibers in diabetic group showed increase in the collagen fibers around the region of portal tract (Fig.7).

The mucopolysacharrides contents in diabetic group show marked decrease in its distribution within the hepatocytes (Fig. 8).

The activity of alkaline phosphatese and succinic dehydrogenase enzymes in diabetic group were decreased (Fig. 14,17). The obtained histochemical changes were confirmed quantitatively by the use of image anaylsis system and statistically analyzed.

\section{c. Effect of sitagliptin (Januvia):}

After oral intake of sitagliptin, the liver structure showed variable microscopic changes in the form of dilated congested central veins and mild cellular infiltrations at the region of portal tract $($ Fig9, 10).

The distributions of collagenous fibers were slightly decreased but do not return to control group (Fig. 11), while the mucopolysacharrides contents in the hepatocyte are more or less similar to those in the control group (Fig. 12).

The activity of both alkaline phosphatese and succinic dehydrogenase enzymes in this group returned back to near its normal when they were compared to the control group (Fig.15 and 18). The obtained histochemical changes were confirmed quantitatively by the use of image anaylsis system and statistically analyzed. 
The effect of Sitagliptin (Januvia) on the liver of adult Albino rats...

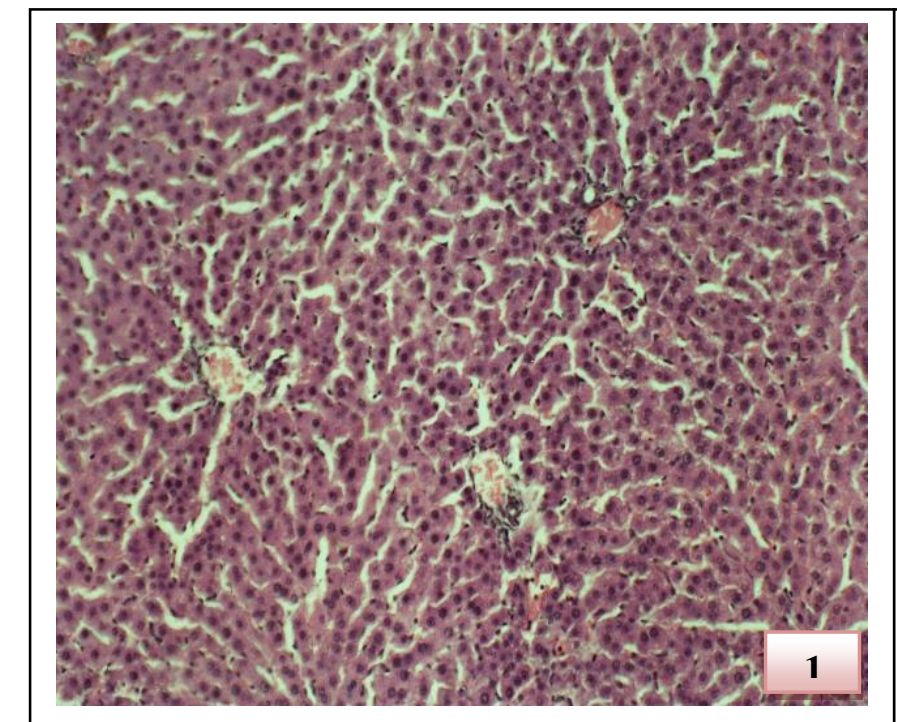

(Fig. 1 ) Photomicrograph of a section in the control liver of albino rat showing the normal structure of the liver cells , Cells are arranged in cords radiating from the central vein ( Hx. \& E. X 200)

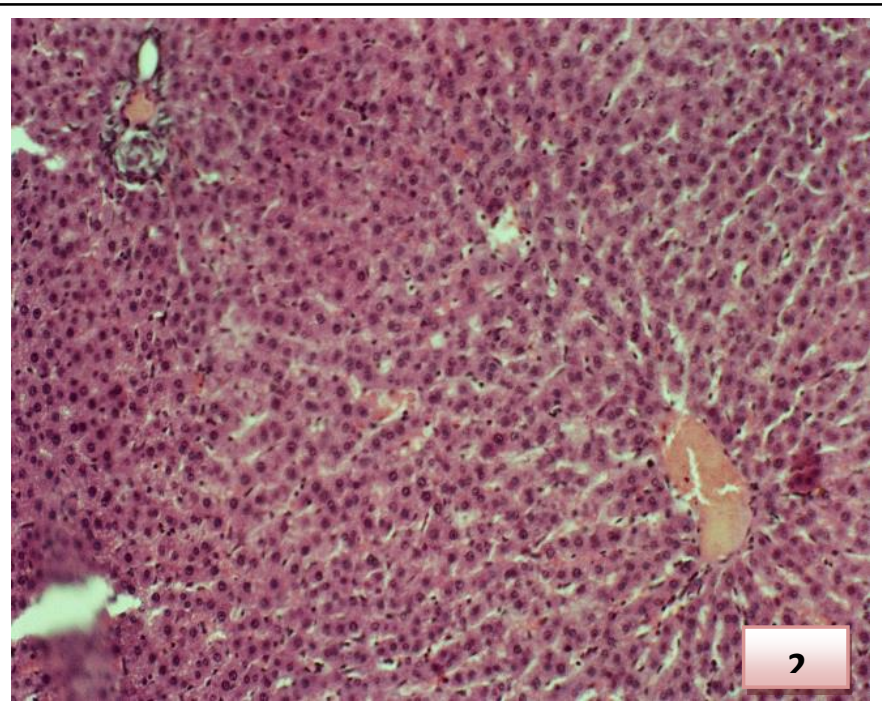

( Fig. 2 ) Photomicrograph of a section in the control liver of albino rat showing the normal structure of the liver cells, the region of the portal tract is seen in the upper left of the figure. ( Hx. \& E. X 200)

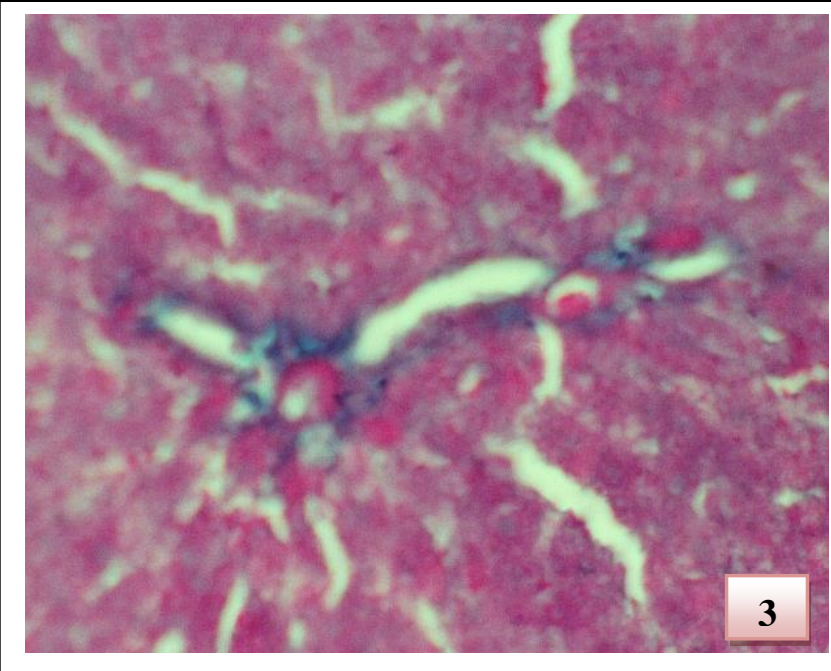

( Fig. 3 ) Photomicrograph of a section in the control liver of albino rat showing the normal distribution of the collagenous fiberes around the region of portal tract ( Trichrome stain X 250)

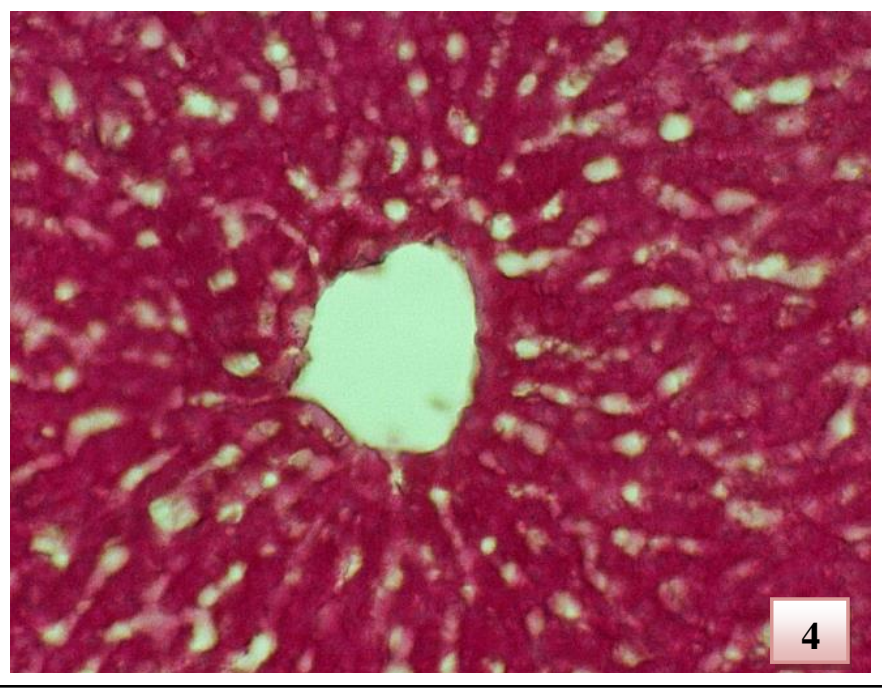

( Fig. 4 ) Photomicrograph of a section in the control liver of albino rat showing the normal distribution of PAS postive material in the liver cells ( PAS technique $X$ 250) 


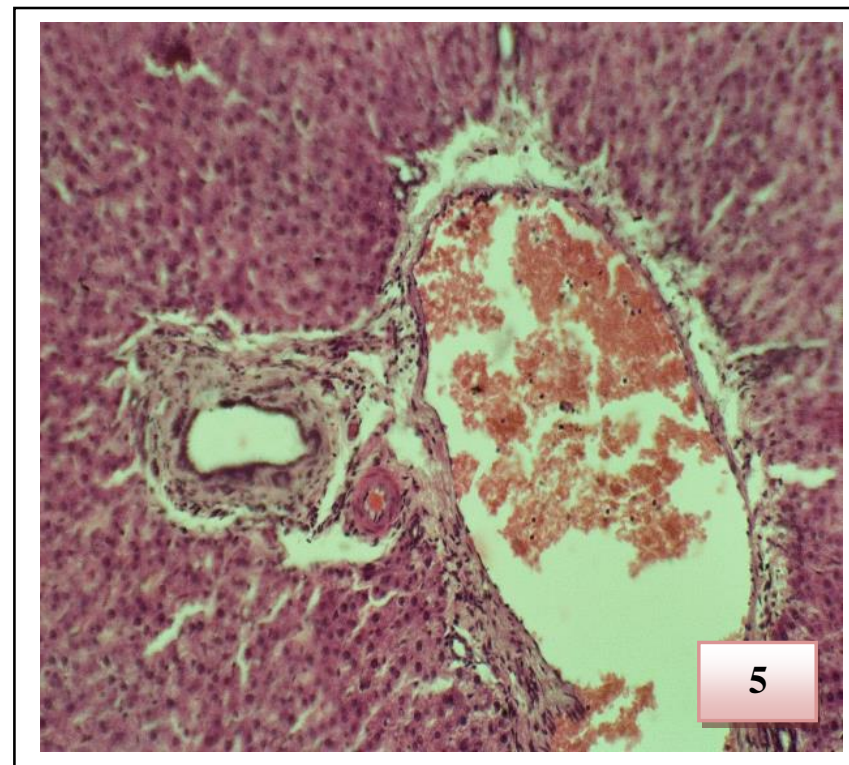

( Fig.5 ) Photomicrograph of a section in liver of induced diabetes of albino rat showing dilated congested vein (Hx.E. stain X 250)

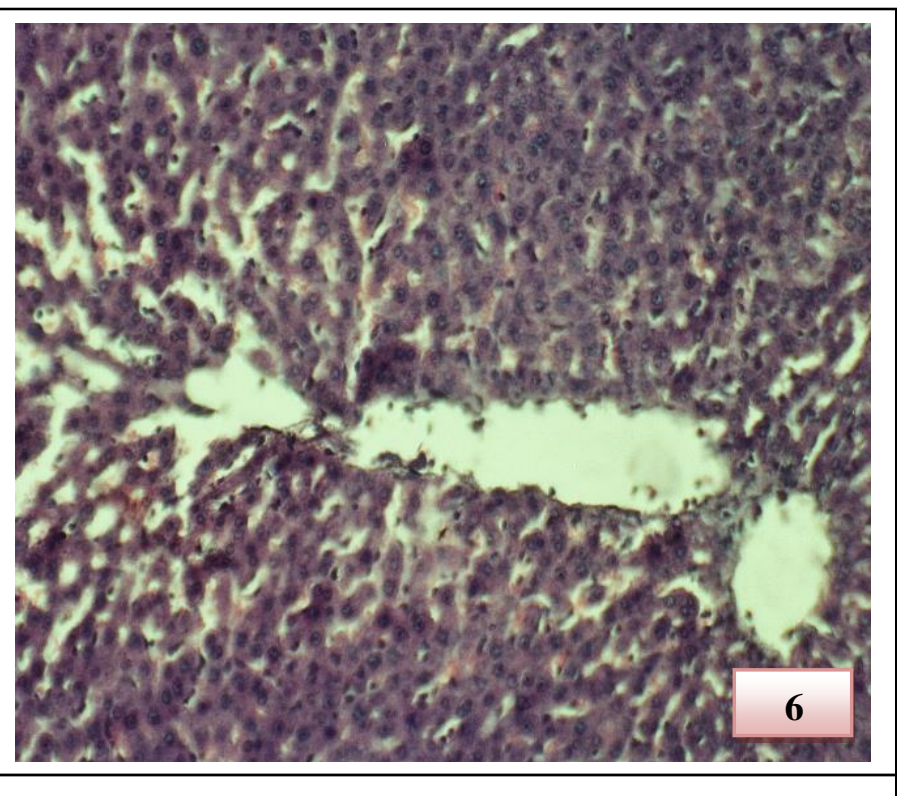

(Fig.6) Photomicrograph of a section in liver of induced diabetes of albino rat showing hepatic cell cords disarrangement (Hx.E. stain X 250)

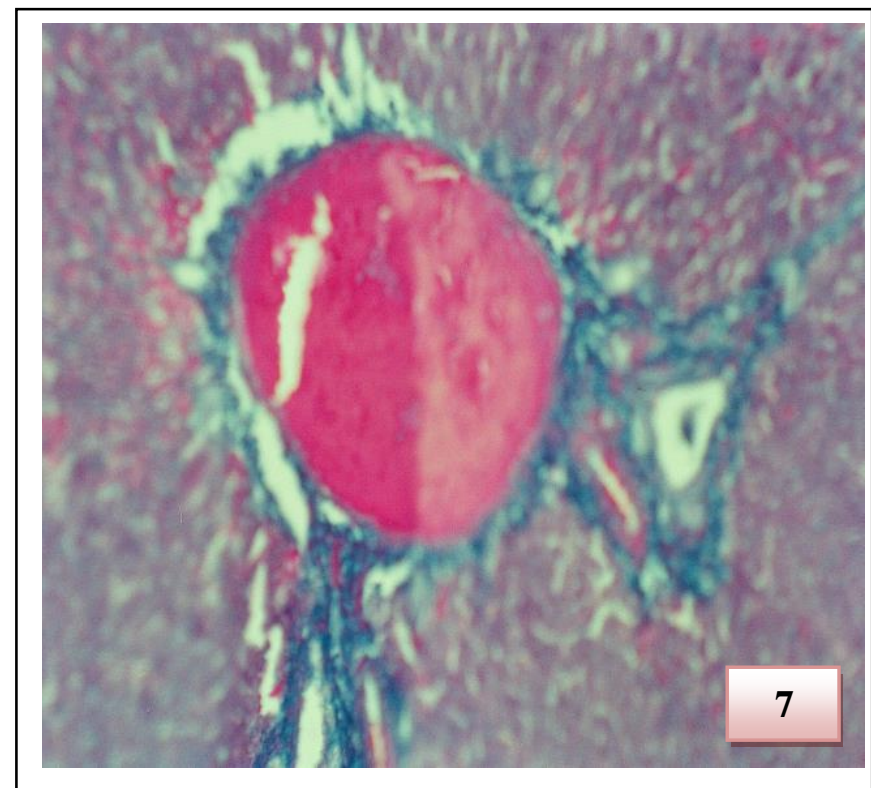

( Fig.7) Photomicrograph of a section in the liver of induced diabetes of albino rat showing the distribution of the collagenous fiberes around the region of portal tract ( Trichrome stain X 250)

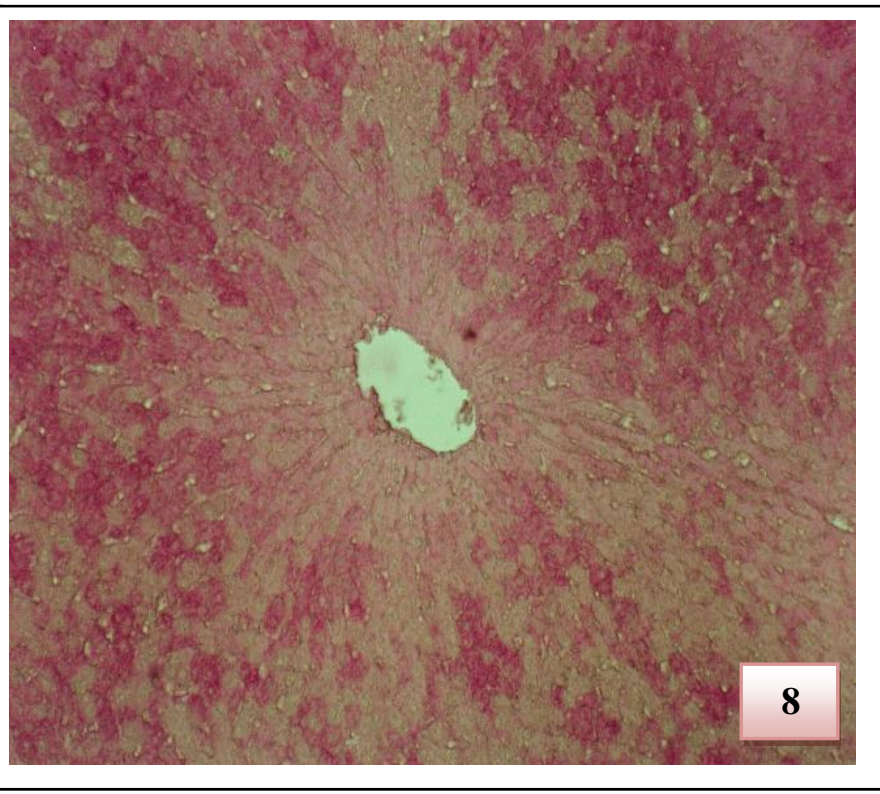

(Fig.8)Photomicrograph of a section in the liver of induced diabetes of albino rat showing the distribution of PAS postive material in the liver cells ( PAS technique $X$ 250) 
The effect of Sitagliptin (Januvia) on the liver of adult Albino rats...
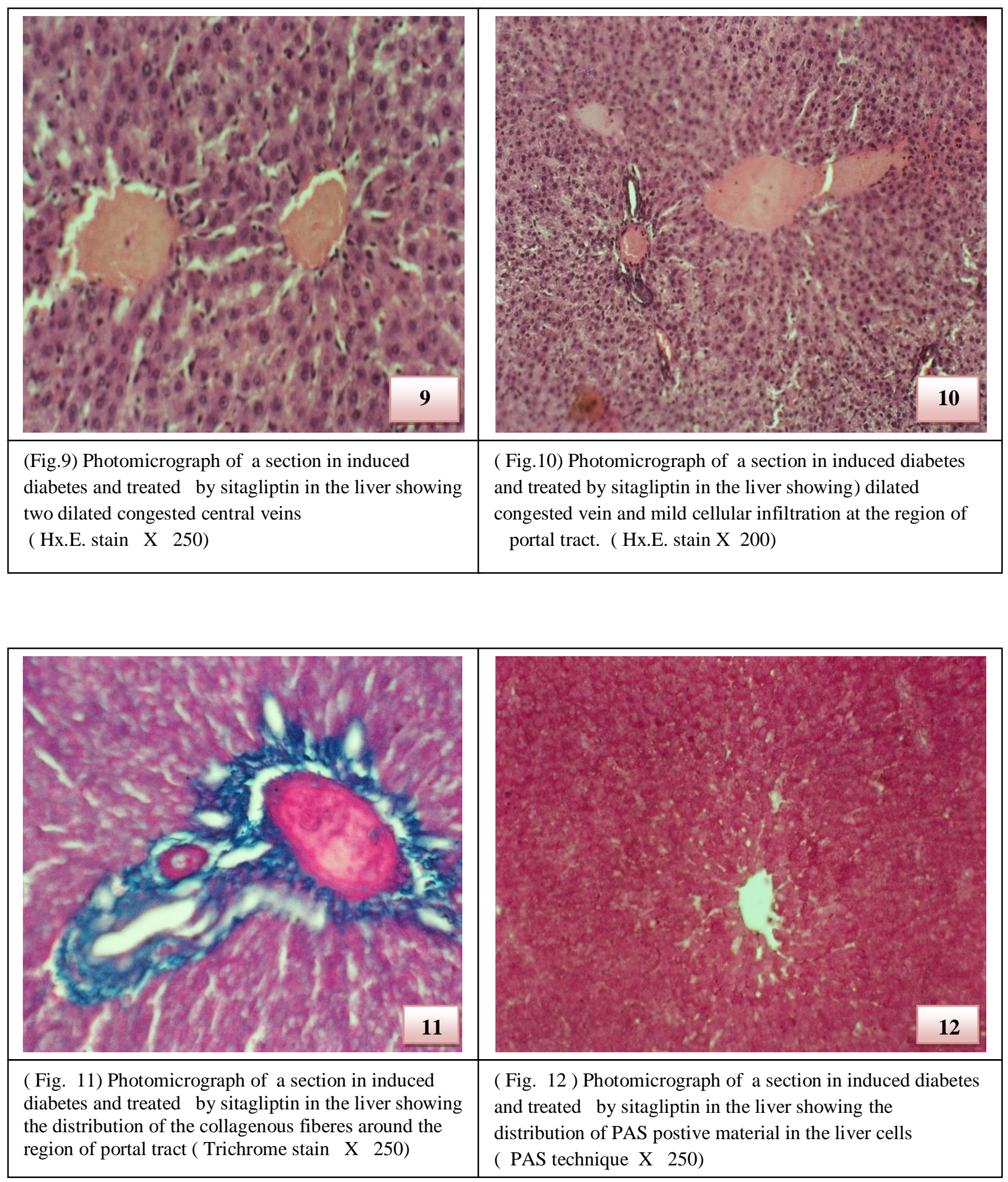


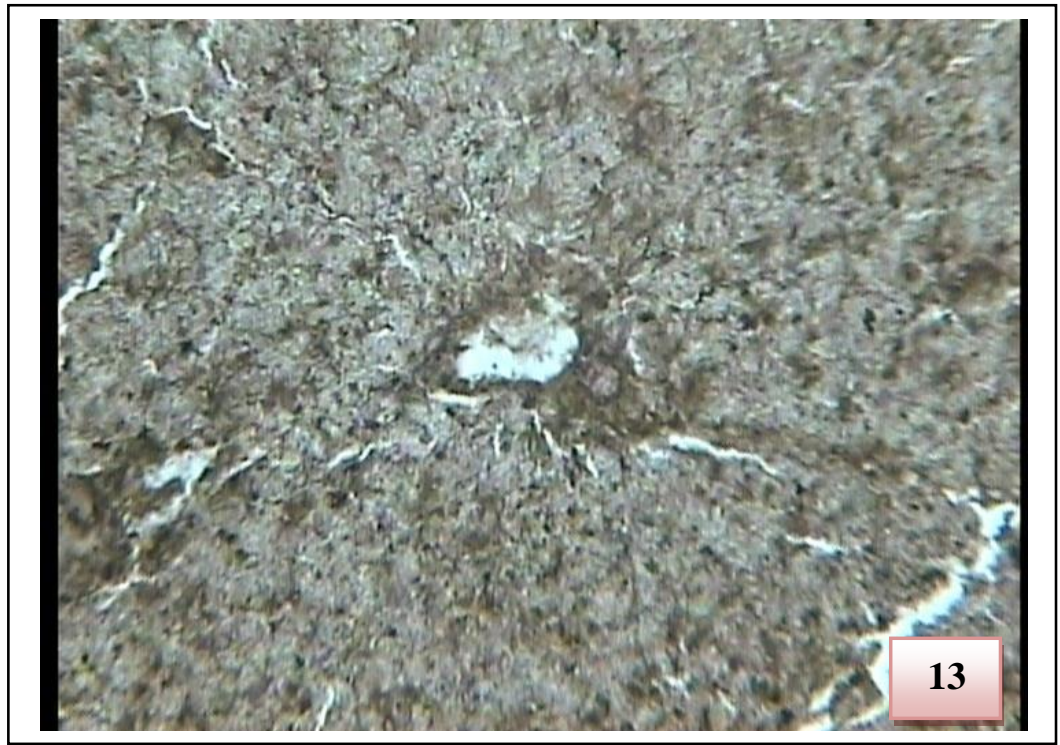

(Fig,13)Photomicrograph of a section in control liver showing alkaline phosphatase enzyme (Modified Gomori stain x 200)

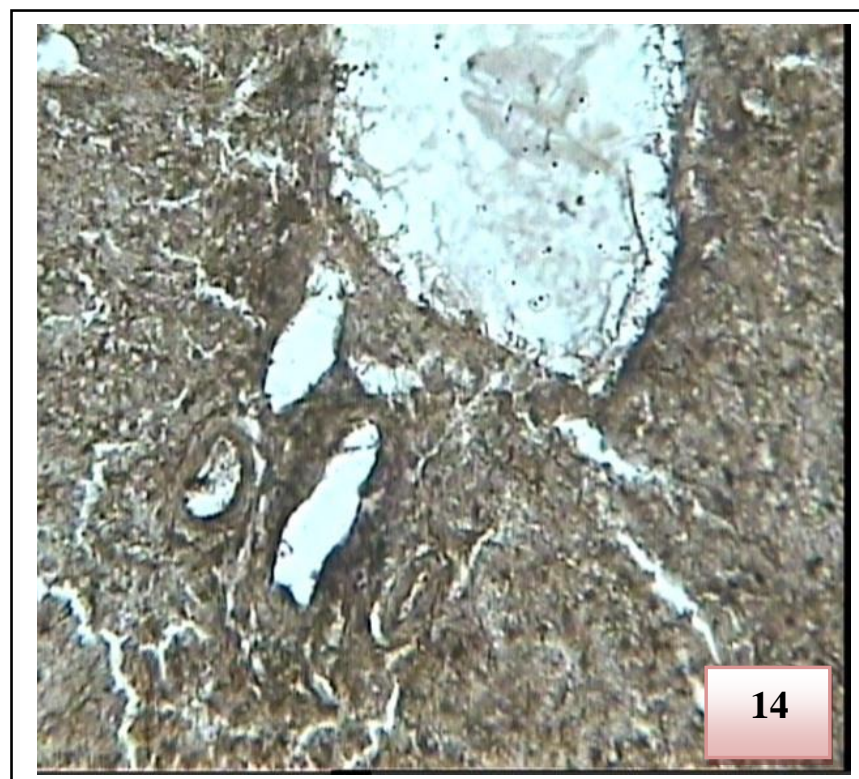

(Fig.14) Photomicrograph of a section in induced diabetes in the liver showing alkaline phosphatase enzyme activity. (Modified Gomori stain x 200)

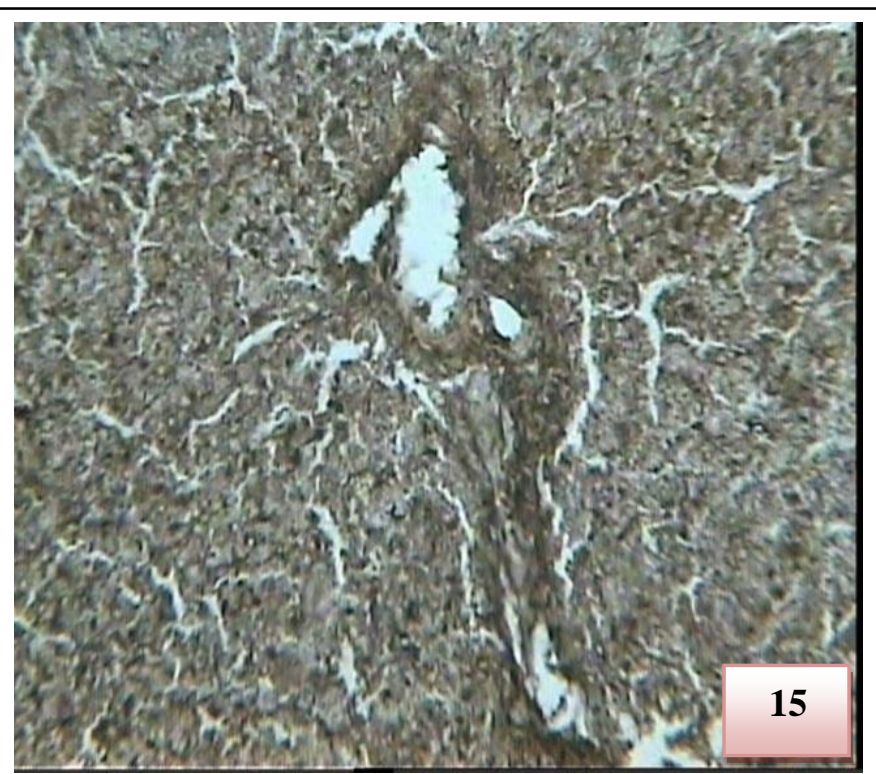

(Fig.15)Photomicrograph of a section in induced diabetes and treated by sitagliptin in the liver showing alkaline phosphatase enzyme activity. (Modified Gomori stain x 200) 

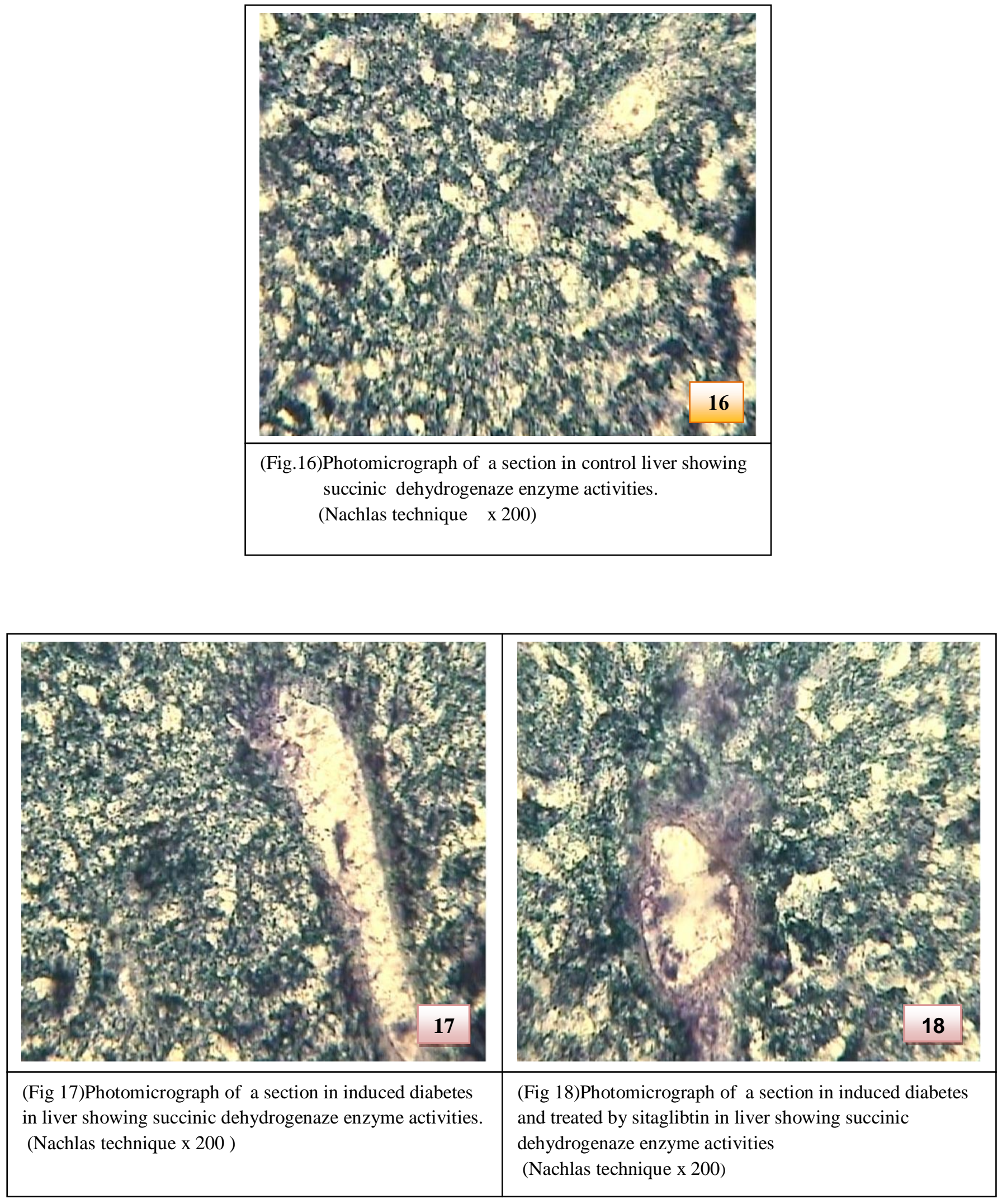
(Table 1) Changes in the mucopolysaccharide contents in the different groups of the study

\begin{tabular}{|c|c|c|c|}
\hline & Control & Diabetic & Treated \\
\hline 1 & 1.12 & 0.36 & 1.02 \\
\hline 2 & 1.13 & 0.4 & 1 \\
\hline 3 & 1.16 & 0.45 & 1.02 \\
\hline 4 & 1.11 & 0.4 & 0.94 \\
\hline 5 & 1.12 & 0.42 & 1.12 \\
\hline mean & 1.128 & 0.406 & 1.02 \\
\hline SD \pm & 0.019 & 0.033 & 0.065 \\
\hline SE \pm & 0.009 & 0.015 & 0.029 \\
\hline Sig. & & Sig. & Sig. \\
\hline
\end{tabular}

(Fig. 19)changes in mucopolysaccarides content in

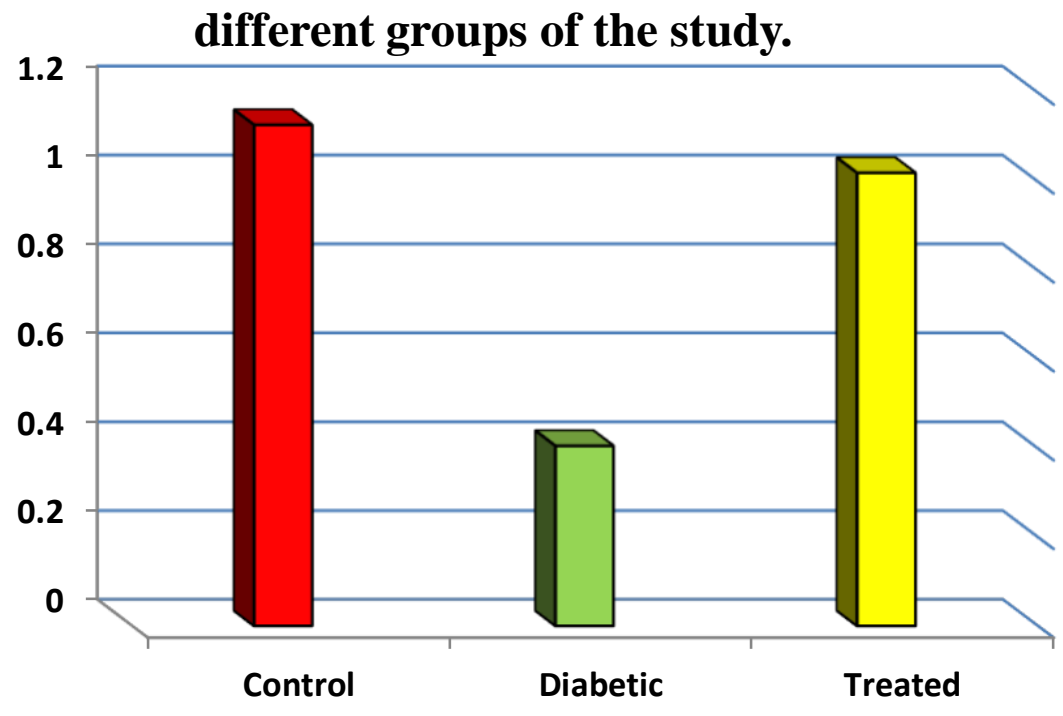


(Table 2) Changes in the alkaline phosphatase enzyme activity in the different groups of the study

\begin{tabular}{|c|c|c|c|}
\hline & Control & Diabetic & Treated \\
\hline 1 & 1.52 & 0.5 & 1.02 \\
\hline 2 & 1.49 & 0.49 & 1.03 \\
\hline 3 & 1.4 & 0.5 & 0.91 \\
\hline 4 & 1.41 & 0.51 & 1.05 \\
\hline 5 & 1.39 & 0.49 & 1 \\
\hline Mean & 1.442 & 0.498 & 1.002 \\
\hline SD \pm & 0.059 & 0.008 & 0.054 \\
\hline SE \pm & 0.026 & 0.004 & 0.024 \\
\hline Sig. & & Sig. & Sig. \\
\hline
\end{tabular}

(Fig. 20) changes in alkaline phosphatase enzyme activity in different groups of the study.

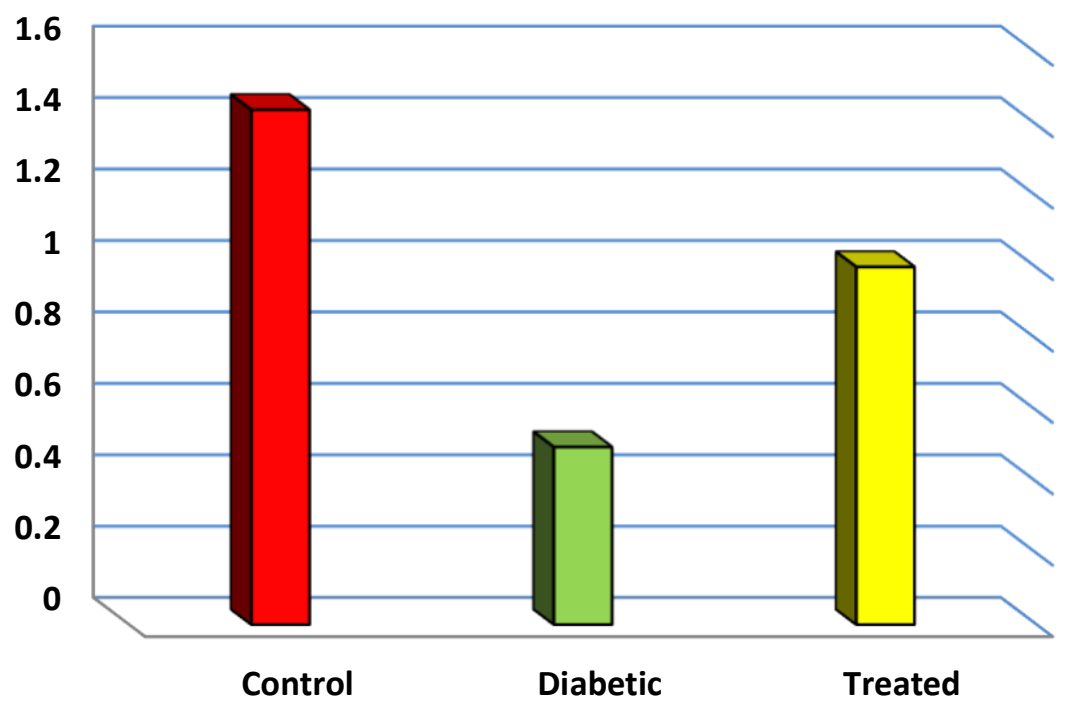


(Table 3) Changes in the succinic dehydrogenase enzyme activity in the different groups of the study

\begin{tabular}{|c|c|c|c|}
\hline & Control & Diabetic & Treated \\
\hline 1 & 1.43 & 0.51 & 1.3 \\
\hline 2 & 1.35 & 0.49 & 1.07 \\
\hline 3 & 1.28 & 0.43 & 0.81 \\
\hline 4 & 1.4 & 0.52 & 0.9 \\
\hline 5 & 1.35 & 0.5 & 1.2 \\
\hline Mean & 1.362 & 0.49 & 1.056 \\
\hline SD \pm & 0.057 & 0.035 & 0.203 \\
\hline SE \pm & 0.026 & 0.016 & 0.091 \\
\hline Sig. & & Sig. & Sig. \\
\hline
\end{tabular}

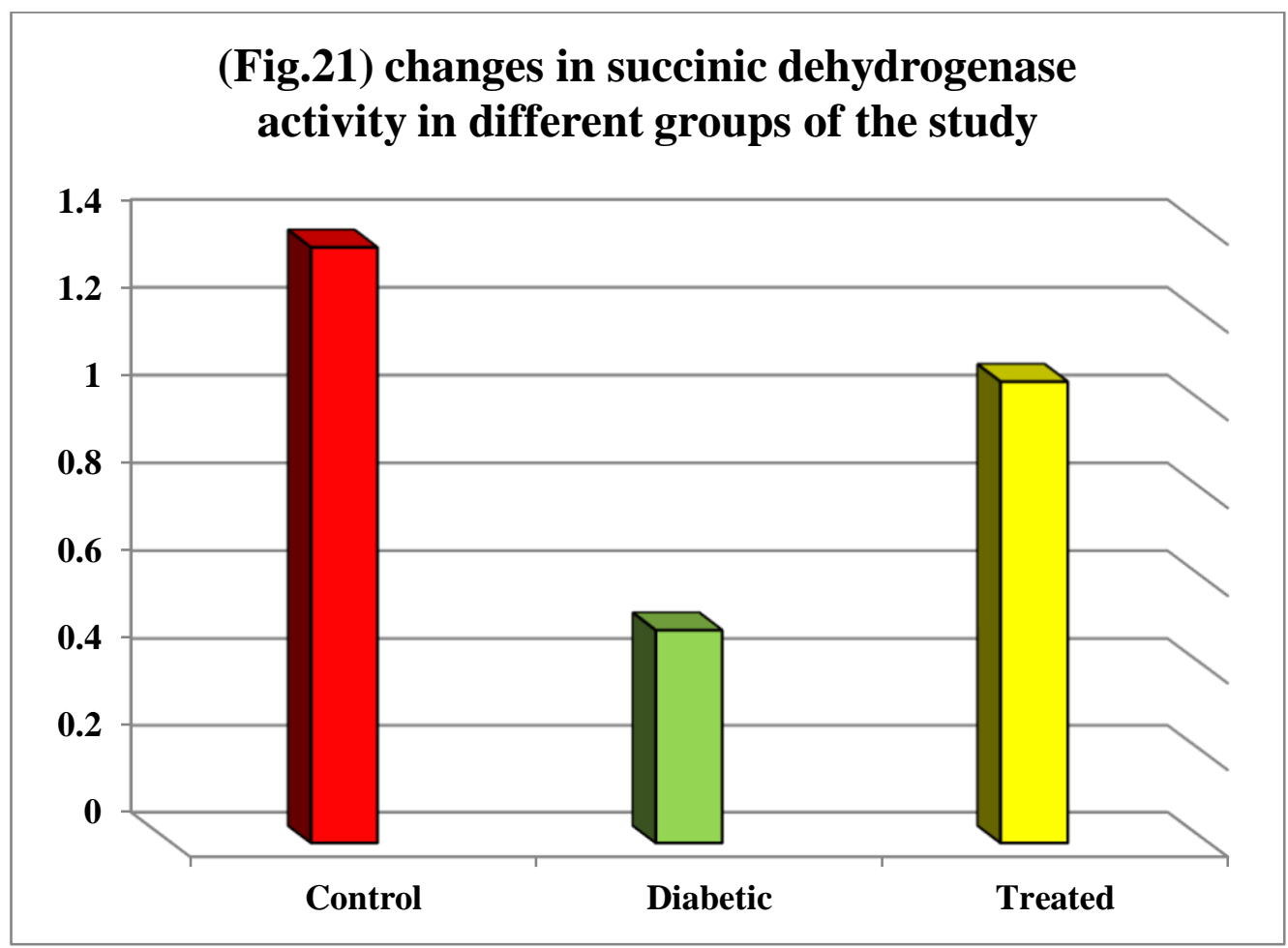


(Table 4) Changes in the blood glucose level in the different groups of the study

\begin{tabular}{|c|c|c|c|c|c|c|}
\hline \multirow{2}{*}{$\frac{\mathscr{\Xi}}{\stackrel{0}{\Xi}}$} & \multicolumn{2}{|c|}{ Control } & \multicolumn{2}{|c|}{ Diabetic } & \multicolumn{2}{|c|}{ Treated diabetes with Januvia } \\
\hline & Before & $\begin{array}{c}\text { (After) } \\
\text { Time of } \\
\text { sampling }\end{array}$ & Before & $\begin{array}{c}\text { (After) } \\
\text { Time of } \\
\text { sampling }\end{array}$ & Before & $\begin{array}{c}\text { After } \\
\text { Treatment }\end{array}$ \\
\hline 1 & 121 & 123 & 272 & 252 & 276 & 78 \\
\hline 2 & 104 & 118 & 236 & 266 & 255 & 75 \\
\hline 3 & 101 & 119 & 243 & 256 & 241 & 103 \\
\hline 4 & 102 & 120 & 280 & 270 & 261 & 112 \\
\hline 5 & 114 & 120 & 215 & 233 & 259 & 89 \\
\hline Mean & 108.4 & 120 & 249.2 & 255.4 & 258.4 & 91.4 \\
\hline $\mathrm{SD} \pm$ & 8.73 & 1.87 & 26.70 & 14.48 & 12.56 & 15.92 \\
\hline $\mathbf{S E} \pm$ & 3.91 & 0.84 & 11.94 & 6.48 & 5.62 & 7.12 \\
\hline Age comp. & \multicolumn{2}{|c|}{ Control : diabetic } & \multicolumn{2}{|c|}{ Control : treated } & \multicolumn{2}{|c|}{ Diabetic : treated } \\
\hline T Value & \multicolumn{2}{|c|}{20.730} & \multicolumn{2}{|c|}{3.991} & \multicolumn{2}{|c|}{17.041} \\
\hline$P$ value & \multicolumn{2}{|c|}{$\geq 0.05$} & \multicolumn{2}{|c|}{$\geq 0.05$} & \multicolumn{2}{|c|}{$\geq 0.05$} \\
\hline Sig. & \multicolumn{2}{|c|}{ Sig. } & \multicolumn{2}{|c|}{ Sig. } & \multicolumn{2}{|c|}{ Sig. } \\
\hline
\end{tabular}

\section{(Fig.22 ) Changes in the blood glucose level in the different groups of the study}

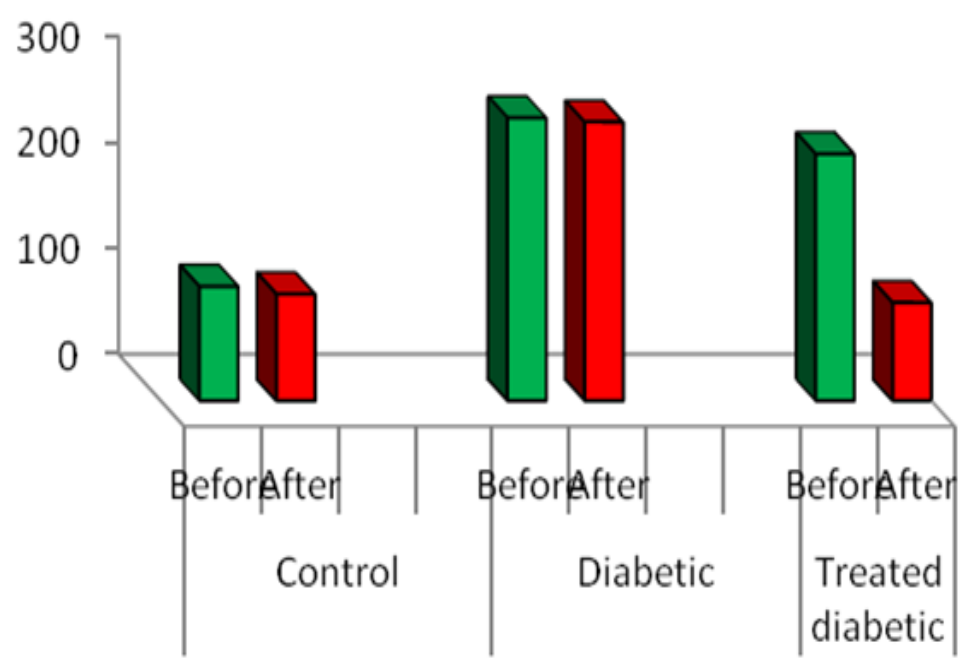


(Table 5) Changes in the serum insulin level in the different groups of the study

\begin{tabular}{|c|c|c|c|}
\hline 章 & Control & Diabetic & $\begin{array}{c}\text { Treated diabetes with } \\
\text { Januvia }\end{array}$ \\
\hline 1 & 37 & 2.8 & 2 \\
\hline 2 & 32 & 2.4 & 2.1 \\
\hline$\overline{3}$ & 30 & 4 & 1.6 \\
\hline 4 & 29 & 4.5 & 2.4 \\
\hline 5 & 25 & 3.5 & 2.2 \\
\hline $\begin{array}{l}\text { Mean } \\
\end{array}$ & 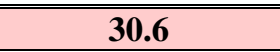 & 3.46 & 2.06 \\
\hline$\overline{\mathrm{SD} \pm}$ & 4.39 & 0.87 & 0.30 \\
\hline$\overline{\mathrm{SE} \pm}$ & 1.96 & $\begin{array}{r}0.39 \\
\end{array}$ & 0.13 \\
\hline Age comp. & Control : diabetic & Control : treated & Diabetic : treated \\
\hline T Value & 13.549 & 14.493 & 3.394 \\
\hline P value & $\geq 0.05$ & $\geq 0.05$ & $\geq 0.05$ \\
\hline Sig. & Sig. & Sig. & Sig. \\
\hline
\end{tabular}

(Fig.23 ) Changes in the serum insulin level in the different groups of the study

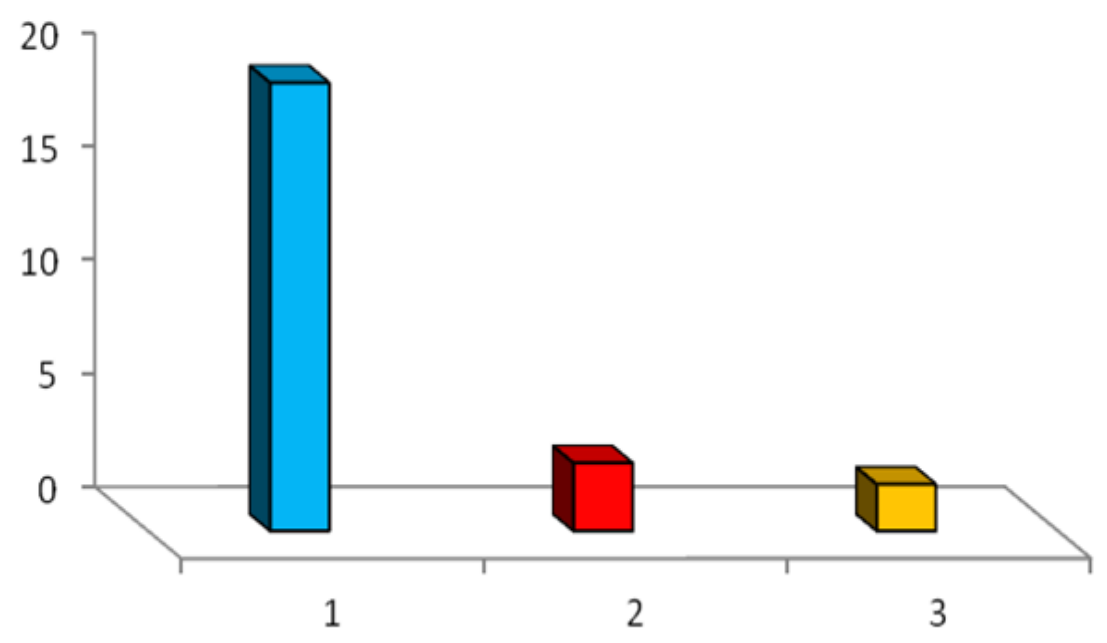


(Table 6) Changes in serum level of Alanine amino transferase in the different groups of the study

\begin{tabular}{|c||c||c||c|}
\hline \multicolumn{1}{|c|}{} & Control & Diabetic & $\begin{array}{c}\text { Treated diabetes with } \\
\text { Januvia }\end{array}$ \\
\hline \hline 1 & 58 & 79 & 81 \\
\hline \hline 3 & 49 & 67 & 66 \\
\hline \hline 5 & 44 & 57 & 90 \\
\hline \hline 5 & 49 & 64 & 88 \\
\hline \hline Mean & 65 & 72 & 89 \\
\hline \hline SD \pm & 53 & 67.8 & 82.8 \\
\hline SE \pm & 8.40 & 8.29 & 10.03 \\
\hline \hline Age comp. & 3.75 & 3.71 & 4.49 \\
\hline \hline T Value & C / D & C/ T & D T \\
\hline \hline P value & 2.805 & 5.093 & 2.577 \\
\hline \hline Sig. & $\geq 0.05$ & $\geq 0.05$ & Sig. \\
\hline
\end{tabular}

\section{(Fig. 24 ) Changes in the serum level of ALAT in the} different groups of the study

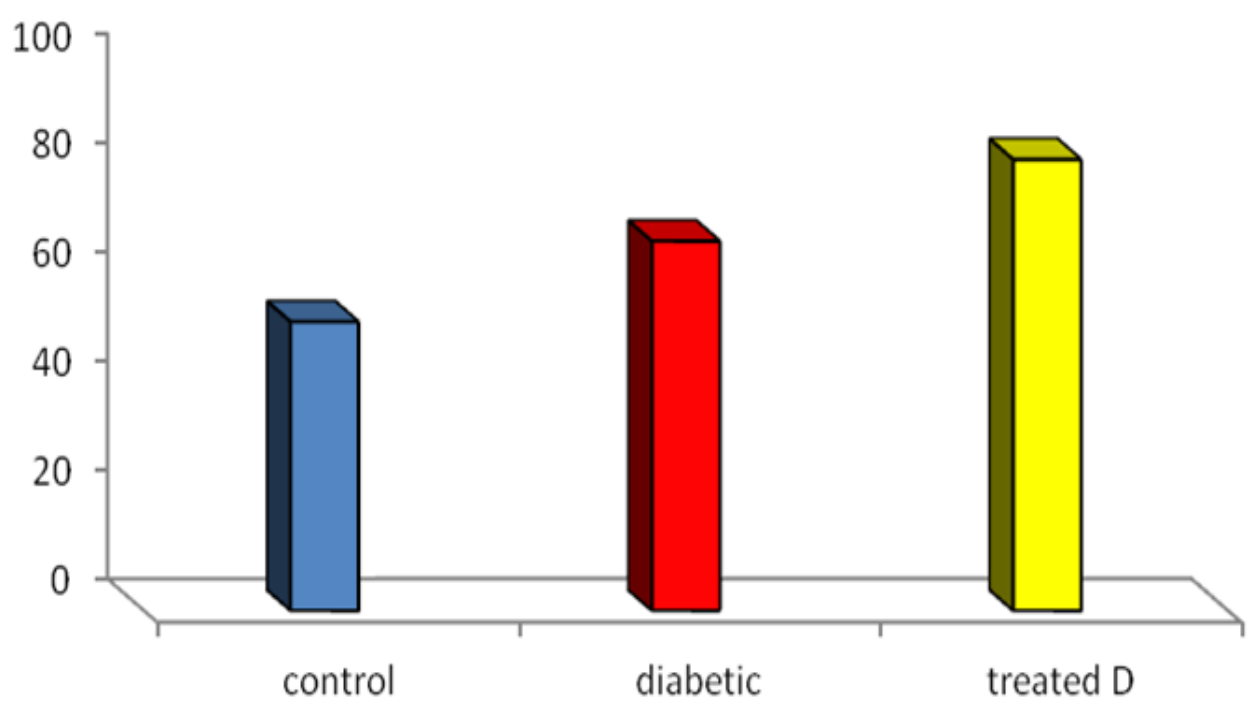


(Table 7) Changes in serum level of (GGT) in the different groups of the study

\begin{tabular}{|c|c|c|c|}
\hline & Control & Diabetic & $\begin{array}{c}\text { Treated diabetes with } \\
\text { Januvia }\end{array}$ \\
\hline$\overline{11}$ & $\overline{11}$ & 2 & $\bar{~} 1$ \\
\hline 2 & 2 & 3 & 2 \\
\hline 3 & 4 & 2 & $\mathbf{1}$ \\
\hline 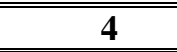 & 1 & 4 & 3 \\
\hline 5 & 1 & 3 & 1 \\
\hline Mean & 1.8 & 2.8 & 1.6 \\
\hline$\overline{S D \pm}$ & 1.30 & 0.84 & 0.89 \\
\hline SE \pm & 0.58 & 0.37 & 0.40 \\
\hline Age comp. & $\overline{C / D}$ & $\overline{\mathrm{C} / \mathrm{T}}$ & $\bar{D} / \mathrm{T}$ \\
\hline T Value & 1.443 & 0.283 & 2.191 \\
\hline P value & $\leq 0.05$ & $\leq 0.05$ & $\leq 0.05$ \\
\hline Sig. & N Sig. & N Sig. & N Sig. \\
\hline
\end{tabular}

(Fig. 25 ) Changes in the serum level of GGT in the different groups of the study

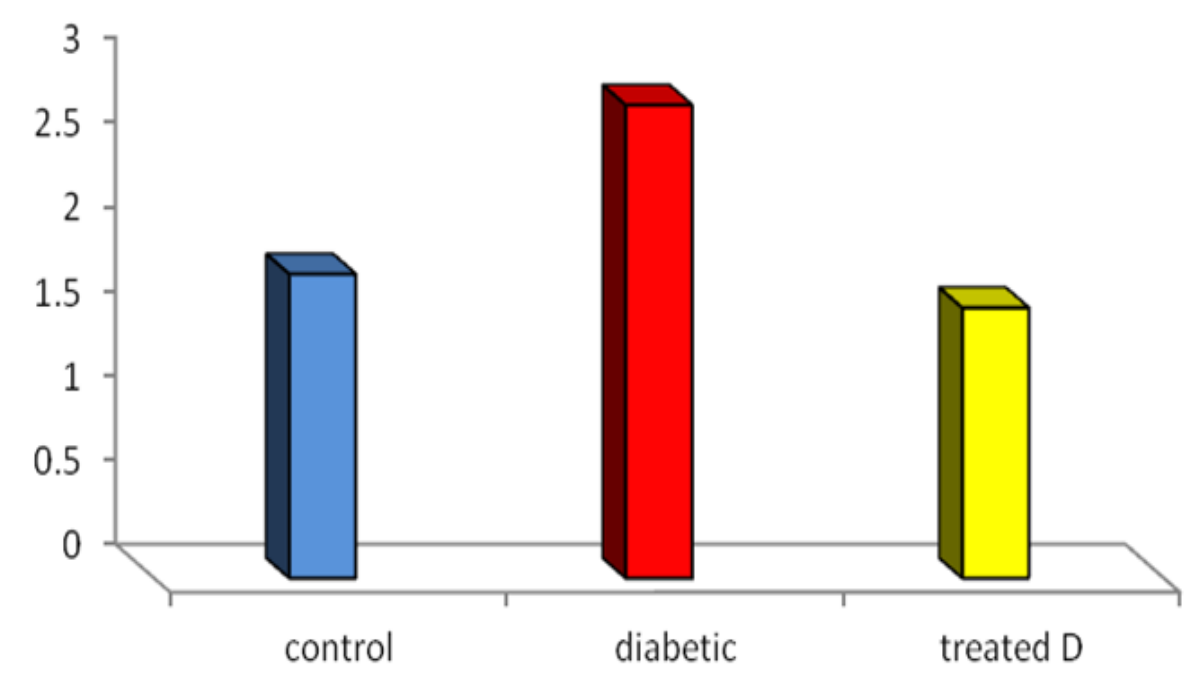




\section{Biochemical parameters:}

\section{a. Blood glucose level:}

There was change in the blood glucose level in the different groups of the study which appear to be normal in control group and increased with induction of diabetes and return to normal level under the effect of sitagliptin (Table 4, Fig22).

\section{b. $\quad$ Serum insulin level $(\mathbf{u} / \mathbf{m l})$ :}

There was change in the serum insulin level in the different groups of the study which appear normal in control group and decreased in both diabetic group and under the effect of sitagliptin.(Table 5,Fig. 23)

\section{c. Liver function tests:}

1. Alanine amino transferase (ALAT):

There was moderate increase in the serum level of alanine amino transferase in the diabetic group which become highly increased in diabetes treated by sitagliptin group (Table 6 , Fig 24).

\section{Gama glutamic transferase (GGT):}

There was highly increase in serum level of (GGT) in diabetic group which return back to normal level under the effect of sitagliptin (Table7,Fig 25).

\section{DISCUSSION}

In this study, adult male albino rats were used and divided into three equal groups. The first group was considered as a control. In the second group experimental induction of diabetes was performed by intraperitoneal injection of alloxan and left as a diabetic control for three weeks. The third group was consisted of rats of experimentally induced diabetes and treated by a daily dose of Sitagliptin (Januvia) drug in a dose of $0.14 \mathrm{mg}$ /100 gm body weight, (Paget, 1964) for three weeks.

In the present study, the microscopic examination of the rat's liver in the second group (induced diabetes) was greatly affecting the normal structure of the liver cellular elements in the form of dilated congested central veins, hepatic cell cords disarrangement, increase in the collagen fibers around the region of portal tract and decrease distribution of hepatic mucopolysacharrides.

Hramiak et al., 1997, support our results and stated that in newly diagnosed diabetes showed higher long-term risk of serious liver affections, including cirrhosis and liver cell failure.

In experimentally diabetic treated rats with oral intake of sitagliptin in group 3 microscopic examination of the liver showed variable microscopic changes in the form of dilated congested central veins and mild cellular infiltrations at the region of portal tract. The distributions of collagenous fibers were slightly decreased but do not return to its normal architecture as in the control group ,while the mucopolysacharrides contents in the hepatocytes were more or less similar to those in the control group .

Horn et al., (1995) reported that the presence of collagen in the presinusoidal spaces might affected the blood supply to liver cells and would be reduce the exchange of metabolism, perhaps causing hepatocellular dysfunction and necrosis.

Sitagliptin is a new class of oral antihyperglycemic drugs known as a DPP-4 inhibitor or incretin enhancer for the treatment of Type II diabetes mellitus, (Amori et al, 2007). Clinical studies have shown improvement in beta-cell function, suggesting a potential for preservation of beta-cells, (Richter, et al.2008).

Abnormalities of triglyceride storage and lipolysis in insulin-sensitive tissues such as the liver lead to abnormal morphological changes in hepatocytes, (Neuschwander-Tetri et al., 2003).

In insulin resistance characteristic of type II, there is increase in the uptake and storage of triglycerides fats from the diet, abdominal fat and nearby muscles into compartments within the hepatocyte vesicles. This infiltration of fat is called steatosis. The results are fatty liver which is larger than normal, (Standards of medical care in diabetes 2011).

Elevated activities of serum aminotransferases are a common sign of liver diseases and are observed more frequently among people with diabetes than in general population, (Arkkila et al., 2001). Serum ALAT, AST and ALP levels were determined to evaluate the hepatic functions, (Degirmenchi et al., 2002). The increase in aminotransferases levels may be due to the cellular damage in the liver caused by alloxaninduced diabetes. Although ALAT is also present in mitochondria and cytosol, the mitochondrial form is low in activity and is very unstable. The detailed mechanism by 
which enzymes are released from the cytosol and mitochondria of hepatocytes is not completely known.

Experimental studies have shown that subtle membrane changes are sufficient to allow passage of intracellular enzymes to the extracellular space, Garella, (1997). Very large concentration gradient between the hepatocytes and the sinusoidal space usually exists for enzymes. Cell damage increases permeability causing cytosolic isoenzymes to spill into the sinusoids and from there into the peripheral blood, Garella, (1997).

Baxter and Schofield, (1980) reported an increase in AST and ALAT in diabetics. This alteration in hepatic function may be because of increase activity and mRNA levels of araginase as reported by Salimuddin $\boldsymbol{e t} \boldsymbol{a l}$. (2008).

Increase in the levels of ALP in diabetic rats was also reported by Ramesh \& Pugalendi,(2006).

\section{References}

1. Akbarzadeh, A. ; Norouzian, D.; Mehrabi, M. R; Jamshidi S; Farhangi, A; Allah, A; Mofidian, S. and Lame, Rad, B. (2007): Induction of diabetes by streptozotocin in rats. IJCB 22: 6064.

2. Amori, R. E; Lau, J. and Pittas, A.G. (2007):Efficacy and safety of incretin therapy in type II diabetes: systematic review and metaanalysis. JAMA; 298:194-206.

3. Arkkila, P. E.; Koskinen, P. J.; Kantola, I. M.; Ronnemaa,T.; Seppanen, E. \& Viikari, J. S.( 2001): Diabetic complications are associated with liver enzyme activities in people with type-1 diabetes. Diabetes Res. Clin. Pract., 52(2):113-8.

4. Baxter, L. C. \& Schofield, P. J.(1980): The effects of a high fat diet on chronic Streptozotocin diabetic rats. Diabetologia, 18(3):239-54.

5. Breuer, J. (1996): Report on the symposium: Drug effects in clinical chemistry methods. Eur. J. Clin. Chem., Clin. Biochem., 34: 385-386.

6. Clayden, E. C. (1971): Practical Section and Staining Churchill Livingstone Edinburgh and London.

7. Davidson, J.A. (2009): Advances in therapy for type II diabetes: GLP-1 receptor agonists and DPP-4 inhibitors. Cleve Clin J Med;76(Suppl. 5):S28-S38pmid:199523011.

8. Degirmenchi, I.; Kalender, S.; Ustuner, M. C.; Kalender, Y.; Gunes, H. V.; Unal, N. \& Basaran, A.(2002): The effects of acarbose and Rumex patientia on liver ultrastructure in
Insulin regulates the entry of glucose into tissues and promotes glycogen storage. Insulin is metabolized in the liver, where it promotes the production of glycogen, protein, cholesterol, and triglycerides and stimulates the formation of low density lipoproteins (LDL), which transport cholesterol into the arteries. In diabetes, excessive output of glucose by the liver contributes to elevated fasting blood sugars, Ghishan ,( 1996).

Davidson et al., (2009) reported that sitagliptin enhance the body's own ability to control blood glucose by increasing the active levels of incretin hormones in the body.

Sitagliptin (DPP-4 inhibitors) control elevated blood glucose by triggering pancreatic insulin secretion, suppressing pancreatic glucagon secretion, and signaling the liver to reduce glucose production. This study open the door for further investigations of other recent oral antidiabetic therapy for better improvement of different diabetic complications.

streptozotocin-induced diabetic (type-II) rats. Drugs Exp. Clin. Res., 28:229-34.

9. Elias, D. ;Prigozin, H.; Polak N. Rapoport, M.; Lohse, A. W. and Cohen, (1994): Autoimmune diabetes induced by the b-Cell toxin STZ. Diabetes 43: 992-8.

10. Garella, S.(1997): The cost of dialysis in the USA. Nephrol. Dial. Transplant., 12:10-2.

11. Ghishan, F. (1996) : Inborn errors of metabolism that lead to permanent liver injury. In Hepatology: A Textbook of Liver Disease. vol. II, 3rd edition. Zakim D and Boyer TD, Eds. Philadelphia, Pa., W.B. Saunders, , 1574-1630.

12. Handelsman,Yehuda,MD(2009): "A Doctor's Diagnosis Prediabetes". Power of Prevention 1 (2).

13. Herman, G. ; Bergman, A. ; Liu, F.; Stevens, C. ; Wang A, Zeng W, Chen L, Snyder K, Hilliard zD, Tanen M, Tanaka W, Meehan A, Lasseter K, Dilzer S, Blum R, Wagner J (2006): "Pharmacokinetics and pharmacodynamic effects of the oral DPP-4 inhibitor sitagliptin in middle-aged obese subjects.". J Clin Pharmacol 46 (8): 876-86. 14. Horn $T$,Jung $J$ and Christoffersen $P$ ( 1995): Alcoholic liver injury : changes of the Disse space in acinar zone. Liver, 91:7-10.

15. Hramiak, I.M; Finegood ,D.T. ; Adams, P.C. (1997): Factors affecting glucose tolerance in hereditary hemochromatosis. Clin Invest Med 20:110-18.

16. Ikebukuro, K. ; Adachi, Y. ;Yamada, Y. ; Fujimoto, S. Seino, Y. Oyaizu, H. (2002): 
Treatment of Streptozotocin-induced diabetes mellitus by transplantation of islet cells Plus bone Marrow cells via portal vein in rats. Transplantation 73: 512-518.

17. Ito, M. (1999): New model of progressive noninsulin-dependent diabetes mellitus in mice induced by Streptozotocin. Biol Pharmaceut Bull 22: 988989.

18. Lambert, P. (2002):"What is Type 1 Diabetes?". Medicine 30:1-5.

19. Malaisse, W.J. (1982): Alloxan toxicity to the pancreatic $\beta$-cell. A new hypothesis. Biochem. Pharmacol., 31: 3527 .

20. Maton, Anthea; Jean Hopkins, Charles William McLaughlin, Susan Johnson, Maryanna Quon Warner, David LaHart, Jill D. Wright (1993): Human Biology and Health. Englewood Cliffs, New Jersey, USA: Prentice Hall. ISBN 0-13981176-1.

21. Nachlas, M.M.; Tsou, K; Desouze, E.; Cheng, M. and Seligmen, A.M. (1957): Cytochemical demonstration of succinic dehydrogenase by the use of new P-nitro phenyl substituted dtetrezole J. histochem. 5: 420-436.

22. Neuschwander-Tetri, B.A; Caldwell, S. (2003): Nonalcoholic steatohepatitis: summary of AASLD single topic conference. Hepatology 37:1202-1219.

23. Ramesh, B. \& Pugalendi, K. V.(2006): Impact of umbelliferone (7 hydroxycourmarin) on hepatic marker enzymes in Streptozotocin diabetic rats. Indian J. Pharmacol.,38:209-10.

24. Reeves, W.G. (1983): Insulin antibody determination: Theoretical and practical consideration. Diabetologia, 24: 339-403.

25. Richter, B. ; Banderia-Echtler, E. ; Bergerhoff, K.and Lerch, C.l. (2008): Dipeptidyl peptidase-4 (DPP-4) inhibitors for type II diabetes mellitus. Cochrane Database of Systematic reviews. CD006739.
26. Rother, K.I. (2007): "Diabetes treatmentbridging the divide". The New England Journal of Medicine 356 : 1499-501.

27. Paget, G. E. and Barnes, J. M. (1964): Evaluation of drug activities pharmacometrics. $1^{\text {st }}$ ed. Laurence, D. R. and Bacharach, A. L., Academic press, London and New York.

28. Pearse, A. (1977): Histochemistry, Theoretical, and Applied. $3^{\text {th }}$ ed., vol. 1.Churchill Livingstone, London.

29. Salimuddin; Upadhyaya, K. C.; Baquer, N. Z.(2008): Effects of vanadate on expression of liver araginase in experimental diabetic rats. IUBMB Life, 48(2):237-40.

30. Snedecor, G.W. and Cochran, W.G. (1980): Statistical Method. State University Press, Lowa, 59 -60 . USA.

31. Standards of medical care in diabetes (2011): Diabetic care. 2011: 34:S 11.

32. Szasz, G. and Persijn, J.P. (1974): Determination of g-glutamy transferas (g-glutamyl) - peptide: amino acid g-glutamyltransferase. Clin. Chem. Biochem., 12: 228 - 238.

33. Takeshita, F. ; Kodama, M. ;Yamamoto, H. ; Ikarashi, Y. ;Ueda S. ; Teratani, T. ; Yamamoto, Y. ; Tamatani, T. ; Kanegasaki, S. Ochiya, T. ; Quinn, G. (2006): .Streptozotocininduced partial beta cell depletion in nude mice without hyperglycaemia induces pancreatic morphogenesis in transplanted embryonic stem cells. Diabetologia.

34. Tarkhan, A. A. (1968 ): Practical Histology, Les Editios Universitaires D'Egypte, Cairo.

35. Trinder, P. (1984): Determination of blood glucose using 4- aminophenazone. J.Clin. Path., 22: 246-252.

36. Wild, S. ; Roglic, G. ; Green, A. ;Sicree, R. ; King, H. (2004):"Global prevalence of diabetes: estimates for 2000 and projections for 2030". Diabetes Care 27 (5): 1047-53. 


\title{
تأثير عقار السيتاجليتين (الجينوفيا) على كبد الجرذان البيضاء البالغه في حالات مرض السكر
}

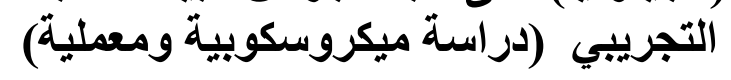

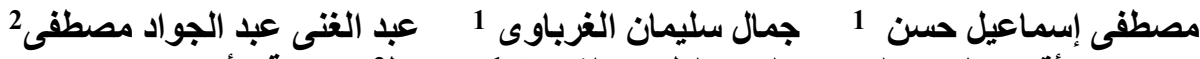

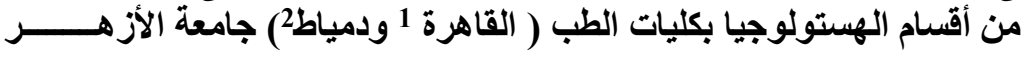

تم إجر اء هذه الدر اسة لتقييم تأثثر عقار السيتاجليبتين ( الجينوفيا) علي كبد الجرذان البيضاء البالغة فى حالات مرض البول السكرى التجريبى.

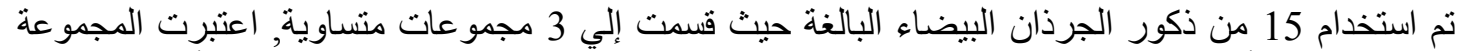

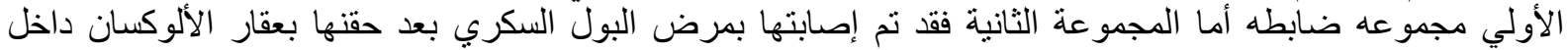

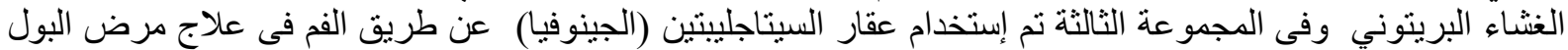

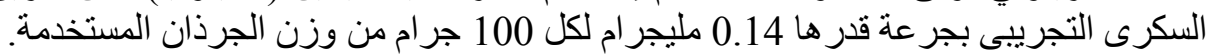

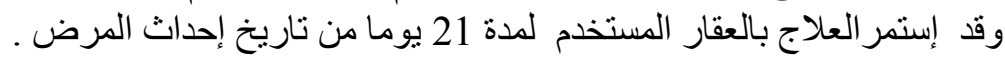

وتم تقسيم النتائج إلى إتجاهين مختلفين شمل الإتجاه الأول دراسة ميكروسكوبية لخلايا الكبد لتتبع التغييرات

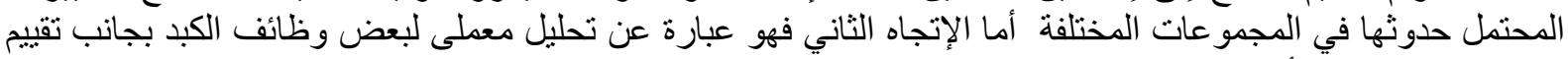

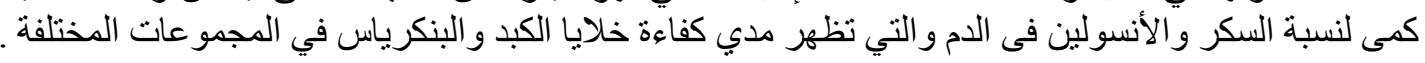

وقد دلت النتائج علي مدي تأثر خلايا الكبد بمرض البول البول السكري فى زيادة الترسيبات الخلوية وعدم إنتظام

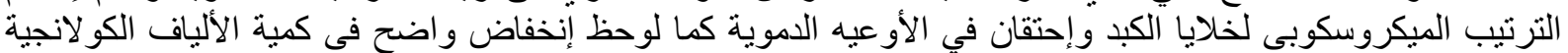

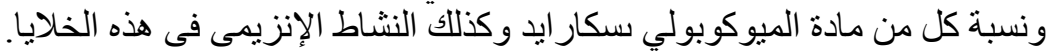

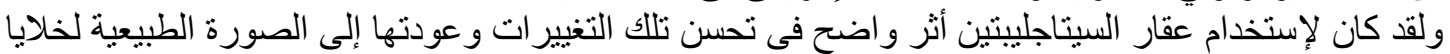

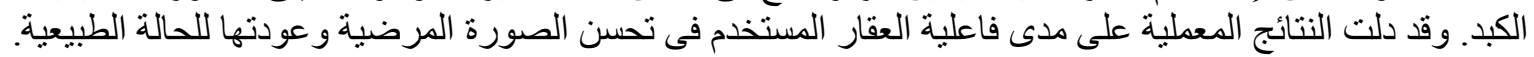
ويستتنج من هذه الدراسة أن عقار السيتاجلييتين (الجينوفيا) له دور جيد في تحسين المضاعفات الناتجة عن تأثير مرض البول السكرى علي خلايا الكبد . 